\title{
CASE STUDY METHOD AS PEDAGOGY IN BUSINESS SCHOOLS: AN INVESTIGATION FROM THE PERSPECTIVE OF INDUSTRY \\ Muhammad Abrar $^{1 *}$, Sajjad Baig ${ }^{2}$, Shahnawaz Saqib ${ }^{3}$, Rizwan Shabbir ${ }^{4}$, Mohsin Bashir ${ }^{5}$
}

$1^{1 *, 4,5}$ Associate Professor, Lyallpur Business School, Government College University, Faisalabad, Pakistan; ${ }^{2}$ Associate Professor, Faisalabad Business School, National Textile University, Faisalabad, Pakistan; ${ }^{3}$ Visiting Lecturer, Department of Management Sciences, Khwaja Fareed University of Engineering and Information Technology, Rahim Yar Khan, Pakistan.

Email: ${ }^{1 *}$ dr.abrargcuf@gmail.com, ${ }^{5}$ mohsinhust@gmail.com

Article History: Received on $12^{\text {th }}$ May 2021, Revised on $25^{\text {th }}$ May 2021, Published on $31^{\text {st }}$ May 2021

\begin{abstract}
Purpose of the study: This study was planned to explore the perception of the business community and their requirement for the skills they see most demanding in business graduates.

Methodology: For this purpose, data were collected from a hundred senior business executives across various industries such as textile and cellular industries to document their perception and requirement. Collected data has been analyzed through statistical techniques and Exploratory Factor Analysis and Mean Attribute Scores.

Main Findings: Study results revealed that the business community seeks seven skills in business graduates, namely, organization skills, interpersonal skills, Ability to analyze skills, problem-solving skills, Ability to think skills, thinking about alternative skills, and strategic planning skills while the Ability to think has been found most demanding talent in the business community.

Applications of this study: This study provides guidelines to the Academia, and industry in devising a mechanism to make more effective business education through case study pedagogy.

Novelty/Originality of this study: From a theoretical perspective, this study provided important insights into literature by exploring the most demanding skills in business graduates, while from a practical standpoint, this study provides a road map for business schools to train their students according to the needs of the business community. Limitations and future directions of the research are discussed.
\end{abstract}

Keywords: Case Study Method, Business Pedagogy, Organization Skills, Interpersonal Skills, Ability to Analyse Skills.

\section{INTRODUCTION}

Pakistan is a developing country having a population of approximately 220 million people with a literacy rate of $60 \%$. There are 155-degree awarding institutes in the country offering higher education to students, including business education. These universities are working in the public and private sector with Higher Education Commission (HEC) as a supervisory body. The university level's enrollment at the university level has approached to a greater extent, out of which the majority are female students. The number of teachers in these universities has reached approximately 84 thousand (Ministry of Federal Education and Professional Training Government of Pakistan, 2015-16). The primary purpose of these universities is to cater to the needs of the industry by providing skilled and trained human resources. The universities design their curriculum and other activities keeping in view the national interests and requirements of the industry. These universities educate the students and make them more practical by training them on the applied side of the research.

Today many business schools follow the case study method of teaching (Herreid, 2011; Herreid \& Schiller, 2013). In all the learning approaches, case studies are the best way of instructing the students due to learning in a memorable context. The students show more presence in classes where instruction is case study teaching (Hoag, Lillie, \& Hoppe, 2005).

The universities offering business education in Pakistan have shown variable performance as the industry often complains about the quality of graduates and research provided to them by universities. In the presence of different education models pursued at our business schools, it seems imperative to investigate these institutions' dynamics and working patterns. Education is a process of learning where information and expertise of a group of people are transmitted from one generation to other through research, teaching, and training. The basic purpose of education in any society is to make the people more productive in terms of their contribution to the national economy. The literacy rate and investment in education in Pakistan are not much appreciated compared to other Asian countries. This situation is evident with the increasing unemployment rate while educational institutes are increasing the enrolment of students. Still, on the other side, the industry is not accommodating business graduates at the same pace. It generates a pool of unemployed business graduates, and this dilemma discloses a gap between the universities and industry (Ministry of Federal Education and Professional Training Government of Pakistan, 2015-16).

The analytical skills and capabilities which business institutions in Pakistan are providing are not up to the standardized level. According to Bekkers \& Freitas, (2011), business education supports, sharpens, and enhances links between industry and Academia by bringing consensus and harmonization. Many pioneering business schools have recognized 
design thinking as searching for ways to help their students become more innovative. Pakistan is bounded with many talented teachers and still requires more exposure in the business domain that might help knowledge seekers quench the thirst and gain deeper insights into the fast-paced challenging of the actual business world arena. Harvard and Oxford methodology are followed in some of the HEC recognized business institutes. Still, it is the need of time to develop the required human resources keeping in view the requirements of the Pakistani environment and industry. To bridge this gap, it is imperative to identify the reasons for this confidence gap by studying the existing curriculum, teaching practices, industry-academia linkages, etc.

\section{Business Education in Pakistan}

To foster economic growth and for the development of human capabilities, education is playing a crucial role through the skills, knowledge, and innovative power of society (Mahmood \& Shafique, 2010). "What universities do with and to students is in large measure a function of the curriculum" (Porter \& McKibbin, 1988). Education is a systematic and organized way of acquiring knowledge by improvising expertise in a particular area. The profession is made up of particular categories of people from whom we can take suggestions and services as they possess mastery skills in their relevant sphere of interest. Among the ample number of forms of education, professional knowledge helps students gaining technical skills and insights besides their basic knowledge. Professional education thus helps people gaining a competitive advantage over others by easily approaching means of living in the current era of cutthroat competition.

Moreover, in the majority of the world, governments have introduced different clutched to enhance organizational performances, develop new courses for the improvement of the education system. The graduates being produced by business institutes have a lack of technical and professional capabilities to adjust to turbulent and complex business environments (Waddock \& Lozano, 2013). Postgraduate and graduate-level courses are offered in MBA, MS, Ph.D., and BBA programs in different business schools of Pakistan. Higher Education Commission of Pakistan (HEC) has developed a detailed roadmap to improve teaching faculty, better access to education reach, ensure distinction in learning and relate the education to the national priories of the country (Ministry of Federal Education and Professional Training Government of Pakistan, 2015-16).

The pedagogy of case studies is now ubiquitous and universal in management education. Business schools are now using this method of pedagogy (Jain, 2005). Cases studies deliver practical and applicable illustrations that can be allied to executives' prior experiences; anchor concepts and theoretical frameworks, analogous settings; provide drama and flamboyant stories that expand attention and retention; inspire involvement and class involvement; and couple information achievement to decision making and action (Barnes, Christensen, \& Hansen, 1994; Garvin, 2003; Merseth \& Lacey, 1993). Harvard Business School has long built its pedagogy around the case study method of instructions.

The pivotal role of business education is to transform students into managers who can help shaping organizations, bringing novelty at the individual or corporate level, resolving disputes, managing conflicts, dealing with excellence at the workplace, etc. Executive education is an imperative and growing activity at business schools today (Gloeckler, 2005). A case study as a pedagogy can provide the most relevant and in-depth knowledge apart from providing excitement and pleasure. Perhaps, it could confound sometimes, but yet is an excellent exercise to enhance analytical skills and promoting lateral Thinking rather than counting on traditional techniques of memorizing the syllabus. Case study encourages students to keenly observe different phenomena, analyzing situations, recalling theories, and building bridges between scenarios and solutions. It supports them pondering over real-life situations which other business executives had been through by putting themselves in their shoes so that they can assess and evaluate conditions based on available information.

Business schools in Pakistan follow two different educational cultures concerning public and private sectors; hence their approach to teaching students differs in methodological perspectives. This results in the production of graduates that are untrained and ill-equipped to handle ambiguous circumstances where relationships and means are unidentified and ends to be sought are vague. The analytical skills and capabilities that are provided by business institutions in Pakistan are not up to the standardized level like those offered in Oxford and Harvard etc. According to Liedtka \& Ogilvie, (2011), business education supports, sharpens, and enhances links between industry and Academia by bringing consensus and harmonization. Many pioneering business schools have recognized design thinking as searching for ways to help their students become more innovative.

\section{What has been done and what is missing}

Business education is competitive since 1992 when around 76 universities were offering different business education programs at bachelor and master level programs in the country. There are numerous disciplines in education, but business education provides directions that help develop personal and professional behavior. This delivers the way how to live with limited resources, how to talk to people, and how to make money, help people and companies in recognizing business opportunities (Kolachi \& Wajidi, 2008). This platform provides distinctiveness in developing human beings to be perfect in numerous domains, particularly in management, psychology, communication, technology, finance, and strategic marketing. Such education delivers a basis to carry companies to competitive paths, provides an opportunity to improve up modern managers' skills, and describes codes of conduct in dealing with the workforce and techniques to conduct business through rational means. Business education enables a person to improve his skills and elevates his 
professional stature. Thus, business graduates are the critical input for the industry. Therefore the industry is concerned about the design and quality of business education to provide skilled human resources, which make their strategic success, a bright possibility. The industry also looks towards universities to solve its problems as such UniversityIndustry association is of dynamic importance for the educational institutions' promotion, development of vivacious industries, and growth of national economies. Unfortunately, in Pakistan, there is a weak relationship between higher education institutions and industry.

Business education is not like other disciplines, which can be learned by sitting in classrooms only. To become successful, a business student needs hands-on training and command on all related subjects. There is a severe disconnection between business education provided in Pakistan and challenges faced by the business sector. What we are doing to experiment in Pakistan is to implement the US model of business education in the country without assessing the specific needs and requirements of the industry. This is not only true in the case of Pakistan instead, at a global level, but it is also a general allegation that business schools are not producing graduates according to the needs of the industry (Bennis \& O'toole, 2005). This happens because most business schools think in their theoretical foundations and give less emphasis to the needs of their clients. A case study may be an activity or problem that will be real or hypothetical in the workplace. It also helps to understand the complexity of real-world problems. The case study describes how problems in real life affect decisions.

Academia and industry are in a relationship with each other to exchange money, people, and knowledge to get the benefit. In a knowledge-based economy, back-and-forth flows of research can generate dollars and discoveries; however, these activities always will not result fruitfully; thus, these activities, in some cases, may lead towards additional resources and prestige for the collaborating partners. Pushing students into a workforce may be the most significant contribution at all in an academic and industry relationship. Case studies are slightly different from experimental studies, which also investigate the phenomena in a real-life context, but in the case of studies, the researcher has less prior knowledge (Cavaye, 1996). Despite this distinction, the difference between these two research methods is a matter of degree, and most of the time it becomes difficult for the researchers to discern.

Case study methods allow the instructor to illustrate a situation in a particular context, and it provides a framework for discussion. The material in case studies can also be changed from real-life situation to describe a specific situation better. Thus there may be different criteria for developing a teaching case study to high-quality case study research (Yin, 1994). Case study research is being used within both positivist and interpretivist philosophical orientations. The positivist perspective is based on ontology, where an objective physical and social world exists independently of humans' knowledge. This approach elaborates that there are regularities, and human beings can just discover them (Orlikowski \& Baroudi, 1991). A trained and specialized business graduate can reinforce institution-industry relations and act as a bridge to build pathways for high-technology fields and jobs (Nind, \& Lewthwaite, 2018). Despite its significance in the past, movements have been initiated by students against the involvement of Academia in external relationships with other stakeholders, which threatened the public-good missions of Academia. Still, after that, many students now extended and pursued entrepreneurship for personal and societal gains (Mars \& Rhoades, 2012).

The relationship between students, Academia, and industry is influenced by a variety of stakeholders. Investment by the Government and Industry in Academia can bring fruitful benefits from an economic point of view, such as students may receive financial returns from their education. Society can benefit from this interaction of Academia and industry, such as "benefit in tax revenue, volunteerism, low crime rates, and, through other channels, increased health and longevity of citizens" (McMahon 2009). This association among higher education institutions, workforce development, and economic growth can attract funding from the government and investment from industry.

\section{Research Objective}

This study aims to address the inconsistency between the skills required of the business community and business graduates being produced by business schools by exploring the perception of business communities their requirement for the skills which they see most demanding in business graduates.

\section{LITERATURE REVIEW}

A case study is concerned with a decision in which people face problems, a challenge, an opportunity, or an organization that deals description of an authentic situation. In a case, it deals with different scenarios and also the beliefs, attitudes, and biases of the people affected, and their instances do not provide explicit answers; rather, cases provoke students' critical Thinking, show them how to think professionally, and recommend students to apply theoretical concepts to show up a practical problem. Through this method, students need to think critically about getting higher-level skills. Case studies allow students to "experience" real customer situations that they may not have access to in real. It includes consideration of the consequences. For instance, in the classroom by revealing hospitality and tourism student to a practical scenario, it grants students a "hands-on" experience that they encourage the growth of critical thinking skills by covering the chance for direct data analysis. They find the best solution in real-life data, and they set the data according to the situation or they find a solution to the office. Meanwhile, the case study depends on the students and the trainer for better solutions and participation (Read \& Kleiner, 1996). The imbalanced involvement of the students during case discussions, the inaccuracy or falsification of the lawsuit, and the outdated case materials are included in the criticism. 
In a case study, context and phenomenon are not readily observable within a real-life setting and in which different ways are used to get evidence in a situation (Yin, 1984). Data collection tools such as questionnaires, consultations, and observations are used in the case study method. Despite their long history, case studies as weak siblings among social science methods have historically been stereotyped. It is considered that researchers who use case studies abandoned their academic areas, and their surveys are classified as lacking in precision, objectivity, and rigor (Nind, 2018).

Higher education plays a very crucial role in the economic development of a nation, and it attracts foreign investment. Higher education has brought a positive change in emerging economies in attaining sustainable economic growth by developing future leaders and pursuing openness in their cultures. In addition to this, higher education also eradicates illiteracy and promotes a knowledge-based economy; this knowledge base economy brings innovations and helps to upgrades a skilled workforce. In emerging economies influx of foreign investment supports the argument that emerging markets, in the future, will be able to excel positively. This foreign investment improves the educational systems and physical infrastructure of a country and strengthens the political institutions. Knowledge management is conceived as an integral part of academic management, although its role in a knowledge-intensive organization becomes dominant (Bratianu, Stanescu, \& Mocanu, 2021).

Multinational companies are an essential source in utilizing the workforce of emerging economies, thus promoting employment growth. International companies push the education system to enhance business education, which can cater to the domestic needs at specific requirements and standards. In the past various researchers have investigated the pedagogical methods in promoting business education. The institutional theory provides a theoretical base under which three tiers of this relationship, i.e., universities, industry, and students, interact. Institutional theory suggests that several organizations and actors are comprised of "rules, reward systems, cognitive-cultural meanings, and taken-for-granted understandings (Campbell, 2007). Business education has helped the economies to modernize the countries' human resources to achieve global economic integration. Business education has enabled the economies to develop a sufficient elastic domestic pool of business leaders. Business education can build the skills of individuals to innovate and compete in global markets; this has resulted in dynamic growth (Bell, 2020).

Emerging economies face a challenge in bringing gradual change in "selection, training, and retention of a world-class, appropriately skilled workforce in the domestic economy." Such a workforce makes an emerging economy autonomous. Emerging markets have to eradicate illiteracy, and at the same time, these government invests in advanced managerial and technical pieces of training. Emerging markets must develop an open educational system that brings attitudinal changes by promoting "competition, quality, openness, responsibility, innovation, and risk-taking through improvement in the quality and openness of educational systems" (Donnorummo, 2002). Similarly, emerging markets can face a drastic challenge of brain drain when the surplus workforce finds external outlets when there are few opportunities in the domestic market.

In traditional classrooms, it is not an easy task to develop an "entrepreneurial mindset," it can be challenging for a teacher to train the students to start a new venture just by traditionally delivering those lectures (Gibb, Hannon, Price, \& Robertson, 2014). Thus in business education training the students to become an entrepreneur requires integrated learning and teaching strategy. In a learning process, pedagogy holds vital significance. Researchers worldwide have recommended that now the emphasis should be on how business education can be taught and what should be taught.

The industry works in association with the academic world; therefore, cutting-edge research can solve the related problems of the age. This transmission of knowledge from academe to industry is of the main focus in well-developed economies of the world. But, the gap between Academia and industry is too extensive in Pakistan. Neither research is formed by industry concerns, nor is it decent enough to speak them anyway. The disinterest from the physical world is also the primary reason that our graduates are believed ill-equipped and insufficient for the professional world when they go outside for job-hunting. The problem is not that business schools have embraced scientific rigor but that they have forsaken other forms of knowledge" (Bennis \& O'toole, 2005). With an increase in the number of diversity and programs, it has triggered the need to incorporate new methods too. Issues are arising concerning content and the process of educating students. Faculty of business schools are devoting their time and energy to discipline-based research, which does not always translate directly into lessons for practising managers (Pfeffer \& Fong, 2002). Many business schools are not opting for professors for their reasonable skill at teaching or provide systematic development opportunities for instructors seeking to broaden or improve their pedagogical skills (Gioia \& Corley, 2002). Although programs today are increasingly emphasizing action-learning approaches, the case method is still used heavily in executive education (Conger \& Xin, 2000). The past studies (Garvin, 2003 and Barnes et al., 1994) reported that cases provide drama and colorful stories that improve retention and attention, couple knowledge achievement to decision making and action, class participation and involvement, anchor theoretical frameworks and concepts in accessible, analogous settings, and provides appropriate examples that can be allied to administrators. Many students are more inductive than deductive, which means they can learn far better when exposed to ambiguous situations are, hence it can grab their attention along with teaching time management. Harvard Business School has long built its pedagogy around the case method of instruction (Cruikshank, 1987).

Case studies are an effective way of motivation building and active engagement. Plausibly, due to employing the latest philosophy of learning in education (constructivism), a case study has become a prominent pedagogy in recent years. 
Learner-centred cases provide a constructive mode of teaching, in which teachers not only transfer knowledge to the students but also build their knowledge in a social, contextual, and interactive setting. By adopting this teaching methodology, students develop multiple pathways for the solutions of the specific circumstances and in the understandings that there may be numerous and acceptable decisions for particular solutions. Consequently, partaking in cases may support generating more questioning and reflective educators. There are many advantages of case studies pedagogy, like diverting emphasis from teacher-oriented to more student-oriented activities and interactive learning approach. Students have to develop multiple potential solutions of open-ended questions in case assignments (Grant, 1997).

The business faculty possess the dynamic and intellectual abilities to serve future business graduates. Heron, Cavico, Mujtaba, \& Pellet, (2007) suggested that an essential mission of business schools is to "look inwardly" at the matters related to business schools administration, courses, faculty, and the students. In contrast, Leydesdorff \& Etzkowitz (1998) stated that the emerging entrepreneurial universities integrated economic development as an additional function in their agenda. Good business schools trained their student to think independently so that they could take the initiative to start up a new enterprise; they were more risk-takers as well innovators and performed tasks in a more organized and unique way. Zgaga et al. (2013) explored that the countries that had not been in the same position of updating their higher education systems had been left behind in the race of development.

Thus, it is imperative to explore the perceptions of the stakeholders i.e., Academia, students, and industry, regarding the essential teaching methods in business education and to develop an educational model with the input of the stakeholders for case study teaching as a pedagogy in business schools of Pakistan.

\section{METHODOLOGY}

This is an exploratory study focused on identifying perceptions of industrialists about business graduates and the skills they want to see in business graduates. Primary data collected from selected respondents and used for identifying factors for improvement of business education in the country. Business graduates are considered important input to the industry as they are expected to enhance efficient utilization of other resources and appraise their owners about possible avenues of profits, losses, and new investments. So the perspective of industry leaders has been sought as to what kind of skills they want to see among business graduates.

\section{Sample Size, Sampling Technique, and Data collection}

This study employs an exploratory research design where the focus was to identify and document the perceptions of stakeholders about the case study method as pedagogy in business schools of Pakistan. A sample of hundred different industrial units was approached for data collection about existing business education pedagogy methods and required skills in business graduates (Ability to think, Ability to Analyze, Time Management, organization skills, thinking about alternative skills, Interpersonal and relationship-building skills, Forward-planning and strategy, Communication Skills, Problem-solving skills, etc.). In this regard leading industries of Pakistan were selected to collect the data such as textile, cellular, banking, and service sector where employment of business graduates is supposed.

\section{Questionnaire/Instrument}

Keeping in view the orientation of this study questionnaires were designed to collect data from industry professionals who are supposed to accept the business graduates for their industry. Thus their perception was quite worthy in this regard. Data from industry professionals was collected in two streams. At the first stage, focus group discussions were carried out with industry professionals, and their perception was sought regarding necessary skills which they want to see among business graduates. Based on this, a set of essential skills was designed, and their relevant questions were framed out at the initial stage. At first, they were asked to report regarding their business/industry domain such as textile, cellular, or services sector, next they were asked to report their working department (HR, Marketing, Finance).

Similarly, they were asked to report their length of service and qualification. In the next section, industry professionals were requested to provide their responses regarding various skills such as Problem Solving Skills, Thinking about Alternatives, Organization Skills, Interpersonal Skills, Ability to think, Ability to analyze, and Strategic Planning Skills. Next, they were asked to report their perception of either they are satisfied with the current employability and skills from business graduates or otherwise. They were supposed to answer this question on a five-point scale including, fully satisfied, Satisfied, Neutral, Dissatisfied, and highly satisfied.

\section{RESULTS/FINDINGS}

Data analysis has been performed in three dimensions; in the first demographic characteristics of the respondents have been reported, while in the second section, results about the Exploratory Factor Analysis (EFA) have been reported under which seven most important skills and their relevant items have been scrutinized. While at the last stage, the ranking of skills according to industry professionals has been arranged based on Mean Attribute Scores. Industry professionals were asked to report their satisfaction with the business graduates. A mixed response has been received from them, and out of a total of 76 respondents, $55 \%$ of respondents indicated that they are satisfied with the present 
level of business graduates. While a handsome composition of respondents also indicated that they are not satisfied with the present level of business graduates (Table 1).

Table 1: Are you satisfied with the current employability and skills of business graduates

\begin{tabular}{lcccc}
\hline Description & Frequency & Percent & Valid Percent & Cumulative Percent \\
\hline Highly dissatisfied & 1 & 1.3 & 1.3 & 1.3 \\
\hline Dissatisfied & 33 & 43.4 & 43.4 & 44.7 \\
\hline Satisfied & 42 & 55.3 & 55.3 & 100 \\
\hline Total & 76 & 100 & 100 & \\
\hline
\end{tabular}

A total of 100 industry professionals having experience of more than five years were approached from various industrial sub-sectors. Out of which, 74 questionnaires were received back, which were considered for final analysis. The distribution of respondents indicates their contribution from various sectors/departments. At the same time, most of the respondents have service experience of 10-15 years, while only $23 \%$ have service length above 15 years. Similarly, both masters and other degree holders share an equal portion in responses (Table 2).

Table 2: Demographic Characteristics

\begin{tabular}{lcc}
\hline Business/Industry Domain & Frequency & Percent \\
\hline Textile & 12 & $16.20 \%$ \\
\hline Cellular & 15 & $20.30 \%$ \\
\hline Banking & 16 & $21.60 \%$ \\
\hline Services & 13 & $17.60 \%$ \\
\hline Other & 18 & $24.30 \%$ \\
\hline Department & & \\
\hline HRM & 19 & $25.70 \%$ \\
\hline Marketing & 19 & $25.70 \%$ \\
\hline Finance & 12 & $16.20 \%$ \\
\hline Other & 24 & $32.40 \%$ \\
\hline Length of Service & & \\
\hline 10-15 Years & 57 & $77 \%$ \\
\hline Above 15 & 17 & $23 \%$ \\
\hline Qualification & & \\
\hline Master & 38 & $51.40 \%$ \\
\hline Other & 36 & $48.60 \%$ \\
\hline
\end{tabular}

\section{Exploratory Factor Analysis (EFA)}

Exploratory Factor Analysis (EFA) was performed using Statistical Package for Social Sciences (SPSS) to examine the uni-dimensionality and extract and explore the underlying indicators against each skill. The first step in EFA is to find out the sample adequacy, for which KMO and Bartlett's test was conducted, which indicated that the sample is of adequate size (0.548), classified as acceptable (Table 3). Regarding Bartlett's Test of Sphericity, the sample correlations of this research are sufficient, being the level of significance 0.000. The Kaiser-Meyer-Olkin (KMO) test helps confirm the suitability of the sample for the degree of correlation, as indicated by Hair et al. (2016).

Table 3: KMO and Bartlett's Test

\begin{tabular}{lll}
\hline \multicolumn{2}{l}{ Kaiser-Meyer-Olkin Measure of Sampling Adequacy. } & $\mathbf{0 . 5 4 8}$ \\
\hline \multirow{3}{*}{ Bartlett's Test of Sphericity } & Approx. Chi-Square & 1701.215 \\
\cline { 2 - 3 } & Df & 435 \\
\cline { 2 - 3 } & Sig. & 0 \\
\hline
\end{tabular}

At the initial stage, commonalities were analyzed, and the loading of each item was assessed for all the 30 items as all the items were loaded by applying Principal Component Analysis (PCA) method (Table 4). The rotational method chosen was the Varimax Rotation, with extraction by the main components method, which indicates a division of the factors in the factorial matrix. The variance explained by using PCA, extracted the sum of squared loading for seven factors. In the rotated sum of squared loading, factor-1 presented $10.893 \%$ of total variance; factor- 2 presented $10.44 \%$ of variance that cumulatively make $21.40 \% \%$ presentation of the scale.

The third factor presented $9.864 \%$ of the variance, and the fourth factor explained $9.818 \%$ of the variance. The other three factors are also adding more variance in factor loading, therefore, this project also considers factor-5, factor- $6 \&$ factor-7, which accounts for $9.386 \%, 8.739 \%$, and $7.580 \%$, respectively. The total cumulative variance of the items is $66.721 \%$. 
Table 4: Factors and their indicators

\begin{tabular}{|c|c|c|c|}
\hline \multirow[t]{2}{*}{ Factor-1= Organization Skills } & Eigenvalue & $\begin{array}{l}\text { Extracted } \\
\text { Variance }\end{array}$ & Alpha \\
\hline & 3.268 & $\mathbf{1 0 . 8 9 3}$ & 0.902 \\
\hline Item Statement & \multicolumn{3}{|c|}{ Factor Loading } \\
\hline OS1 They are able to supply their knowledge to address your firm's needs & \multicolumn{3}{|l|}{0.943} \\
\hline $\begin{array}{l}\text { Graduates are self-believer as leaders and help to manage the } \\
\text { workload of the organizations }\end{array}$ & \multicolumn{3}{|l|}{0.904} \\
\hline Graduates readily adapt according to the firm's environment & \multicolumn{3}{|l|}{0.763} \\
\hline Graduates follow rules and regulation of firms & \multicolumn{3}{|l|}{0.840} \\
\hline \multirow[t]{2}{*}{ Factor-2= Interpersonal skills } & Eigenvalue & $\begin{array}{l}\text { Extracted } \\
\text { Variance }\end{array}$ & Alpha \\
\hline & 3.132 & 10.44 & 0.936 \\
\hline Item Statement & \multicolumn{3}{|c|}{ Factor Loading } \\
\hline IPS1 Verbal communication of graduates is satisfactory & \multicolumn{3}{|c|}{0.885} \\
\hline IPS2 Written communication of graduates is satisfactory & \multicolumn{3}{|l|}{0.941} \\
\hline Graduates are responsive and effective in their communication & \multicolumn{3}{|l|}{0.894} \\
\hline \multirow[t]{2}{*}{ Factor-3= Ability to Analyze } & Eigenvalue & $\begin{array}{l}\text { Extracted } \\
\text { Variance }\end{array}$ & Alpha \\
\hline & 2.959 & 9.864 & 0.954 \\
\hline Item Statement & \multicolumn{3}{|c|}{ Factor Loading } \\
\hline AA1 They work confidently as a team member & \multicolumn{3}{|l|}{0.919} \\
\hline $\begin{array}{ll}\text { AA2 } & \begin{array}{l}\text { The behavior of graduates on the job is optimistic (positive } \\
\text { Thinking) }\end{array}\end{array}$ & \multicolumn{3}{|l|}{0.912} \\
\hline $\begin{array}{ll}\text { Graduates have the capability to work with changing/ new } \\
\text { AA4 management with the same spirit }\end{array}$ & 0.936 & & \\
\hline \multirow[t]{2}{*}{ Factor-4= Problem Solving Skills } & Eigenvalue & $\begin{array}{l}\text { Extracted } \\
\text { Variance }\end{array}$ & Alpha \\
\hline & 2.945 & 9.818 & 0.951 \\
\hline Item $\quad$ Statement & \multicolumn{3}{|c|}{ Factor Loading } \\
\hline $\begin{array}{ll}\text { PSS1 } & \begin{array}{l}\text { Business Graduates think and work independently to sort out } \\
\text { solution to problems }\end{array}\end{array}$ & \multicolumn{3}{|l|}{0.905} \\
\hline $\begin{array}{l}\text { BSS2 } \\
\text { about any business problem facing the firm }\end{array}$ & \multicolumn{3}{|l|}{0.954} \\
\hline $\begin{array}{ll}\text { PSS4 } & \begin{array}{l}\text { Management appreciates Business graduate's generated innovative } \\
\text { ideas }\end{array} \\
\end{array}$ & 0.948 & & \\
\hline \multirow[t]{2}{*}{ Factor-5= Strategic Planning Skills } & Eigenvalue & $\begin{array}{l}\text { Extracted } \\
\text { Variance }\end{array}$ & Alpha \\
\hline & 2.816 & 9.386 & 0.929 \\
\hline Statement & \multicolumn{3}{|c|}{ Factor Loading } \\
\hline SPS1 Graduates have leadership qualities & \multicolumn{3}{|l|}{0.893} \\
\hline SPS2 Graduates work with their colleagues in friendly environment & 0.929 & & \\
\hline $\begin{array}{ll}\text { SPS4 } & \begin{array}{l}\text { Graduates have requisite level of confidence required by the } \\
\text { industry }\end{array}\end{array}$ & 0.913 & & \\
\hline Factor $-6=$ Ability to think & Eigenvalue & $\begin{array}{l}\text { Extracted } \\
\text { Variance }\end{array}$ & Alpha \\
\hline & 2.622 & 8.739 & $\mathbf{0 . 8 5 8}$ \\
\hline Statement & Factor Load & ing & \\
\hline $\begin{array}{l}\text { ATT1 University graduates fulfill your expectations in terms of IQ level } \\
\text { and intellectual Ability }\end{array}$ & 0.850 & & \\
\hline $\begin{array}{l}\text { ATT2 Graduates explore extra resources/ links to address to answer } \\
\text { assigned tasks to them }\end{array}$ & 0.701 & & \\
\hline $\begin{array}{l}\text { ATT3 Graduates have general knowledge about macroeconomic and } \\
\text { current issues of the country }\end{array}$ & 0.895 & & \\
\hline Factor-7 $=$ Thinking about alternative & Eigenvalue & $\begin{array}{l}\text { Extracted } \\
\text { Variance }\end{array}$ & Alpha \\
\hline & 2.274 & 7.58 & 0.947 \\
\hline Statement & Factor Load & ing & \\
\hline
\end{tabular}


TAS2 Graduates produced by private universities are more innovative in 0.865 their approach

TAS3 Graduates have Ability to work in challenging business 0.851 environment to handle the situation

Table 5: Overall Sectors

\begin{tabular}{|c|c|c|c|c|c|c|c|}
\hline Ranking & 1 & 2 & 3 & 4 & 5 & 6 & 7 \\
\hline Indicator & $\begin{array}{c}\text { Ability to } \\
\text { think }\end{array}$ & $\begin{array}{l}\text { Organization } \\
\text { Skills }\end{array}$ & $\begin{array}{l}\text { Interpersonal } \\
\text { Skills }\end{array}$ & $\begin{array}{l}\text { Ability to } \\
\text { analyze }\end{array}$ & $\begin{array}{l}\text { Thinking about } \\
\text { alternatives }\end{array}$ & $\begin{array}{c}\text { Problem- } \\
\text { solving skills }\end{array}$ & $\begin{array}{c}\text { Strategic } \\
\text { Planning } \\
\text { Skills }\end{array}$ \\
\hline Mean & 4.374 & 4.173 & 4.000 & 3.910 & 3.588 & 3.414 & 3.414 \\
\hline $\begin{array}{l}\text { Std. } \\
\text { Deviation }\end{array}$ & 0.933 & 0.524 & 1.321 & 1.190 & 1.536 & 1.402 & 1.055 \\
\hline Skewness & -1.376 & -0.789 & -0.944 & -0.615 & -0.453 & -0.211 & -0.882 \\
\hline Kurtosis & 0.631 & -0.153 & -0.595 & -1.101 & -1.490 & -1.378 & -0.388 \\
\hline \multicolumn{8}{|c|}{ Textile Sector } \\
\hline Ranking & 1 & 2 & 3 & 4 & 5 & 6 & 7 \\
\hline Indicator & $\begin{array}{l}\text { Ability to } \\
\text { analyze }\end{array}$ & $\begin{array}{c}\text { Interpersonal } \\
\text { Skills }\end{array}$ & $\begin{array}{c}\text { Ability to } \\
\text { think }\end{array}$ & $\begin{array}{c}\text { Organization } \\
\text { Skills }\end{array}$ & $\begin{array}{c}\text { Strategic } \\
\text { Planning Skills }\end{array}$ & $\begin{array}{c}\text { Thinking about } \\
\text { alternatives }\end{array}$ & $\begin{array}{c}\text { Problem- } \\
\text { solving skills }\end{array}$ \\
\hline Mean & 4.333 & 4.222 & 4.167 & 4.067 & 3.861 & 3.792 & 3.278 \\
\hline $\begin{array}{l}\text { Std. } \\
\text { Deviation }\end{array}$ & 0.841 & 1.242 & 1.030 & 0.705 & 0.627 & 1.616 & 1.399 \\
\hline Skewness & -0.897 & -1.407 & -1.121 & -0.616 & -2.615 & -1.003 & -0.064 \\
\hline Kurtosis & -0.586 & 1.113 & -0.312 & -1.236 & 8.635 & -0.679 & -1.727 \\
\hline \multicolumn{8}{|c|}{ Cellular Sector } \\
\hline Ranking & 1 & 2 & 3 & 4 & 5 & 6 & 7 \\
\hline Indicator & $\begin{array}{c}\text { Ability to } \\
\text { think }\end{array}$ & $\begin{array}{c}\text { Organization } \\
\text { Skills }\end{array}$ & $\begin{array}{l}\text { Ability to } \\
\text { analyse }\end{array}$ & $\begin{array}{c}\text { Interpersonal } \\
\text { Skills }\end{array}$ & $\begin{array}{c}\text { Thinking about } \\
\text { alternatives }\end{array}$ & $\begin{array}{c}\text { Strategic } \\
\text { Planning Skills }\end{array}$ & $\begin{array}{c}\text { Problem- } \\
\text { solving skills }\end{array}$ \\
\hline Mean & 4.667 & 4.187 & 3.800 & 3.689 & 3.633 & 3.311 & 3.244 \\
\hline $\begin{array}{l}\text { Std. } \\
\text { Deviation }\end{array}$ & 0.735 & 0.612 & 1.326 & 1.389 & 1.778 & 1.116 & 1.702 \\
\hline Skewness & -2.679 & -1.190 & -0.451 & -0.636 & -0.792 & -1.264 & -0.145 \\
\hline Kurtosis & 7.615 & 0.640 & -1.701 & -0.970 & -1.326 & -0.086 & -1.895 \\
\hline \multicolumn{8}{|c|}{ Banking Sector } \\
\hline Ranking & 1 & 2 & 3 & 4 & 5 & 6 & 7 \\
\hline Indicator & $\begin{array}{c}\text { Organization } \\
\text { Skills }\end{array}$ & $\begin{array}{l}\text { Ability to } \\
\text { analyze }\end{array}$ & $\begin{array}{c}\text { Ability to } \\
\text { think }\end{array}$ & $\begin{array}{l}\text { Interpersonal } \\
\text { Skills }\end{array}$ & $\begin{array}{c}\text { Problem- } \\
\text { solving skills }\end{array}$ & $\begin{array}{c}\text { Thinking } \\
\text { about } \\
\text { alternatives }\end{array}$ & $\begin{array}{c}\text { Strategic } \\
\text { Planning } \\
\text { Skills } \\
\end{array}$ \\
\hline Mean & 4.225 & 4.146 & 4.125 & 3.771 & 3.771 & 3.750 & 3.125 \\
\hline $\begin{array}{l}\text { Std. } \\
\text { Deviation }\end{array}$ & 0.425 & 1.186 & 1.115 & 1.618 & 1.479 & 1.571 & 1.147 \\
\hline Skewness & -0.710 & -1.122 & -0.936 & -0.769 & -0.766 & -0.590 & -0.274 \\
\hline Kurtosis & 0.034 & -0.244 & -0.537 & -1.261 & -0.951 & -1.644 & -1.130 \\
\hline \multicolumn{8}{|c|}{ Service Sector } \\
\hline Ranking & 1 & 2 & 3 & 4 & 5 & 6 & 7 \\
\hline Indicator & $\begin{array}{c}\text { Ability to } \\
\text { think }\end{array}$ & $\begin{array}{l}\text { Organization } \\
\text { Skills }\end{array}$ & $\begin{array}{l}\text { Interpersonal } \\
\text { Skills }\end{array}$ & $\begin{array}{c}\text { Strategic } \\
\text { Planning Skills }\end{array}$ & $\begin{array}{l}\text { Ability to } \\
\text { analyze }\end{array}$ & $\begin{array}{l}\text { Problem- } \\
\text { solving skills }\end{array}$ & $\begin{array}{c}\text { Thinking } \\
\text { about } \\
\text { alternatives }\end{array}$ \\
\hline Mean & 4.385 & 4.292 & 3.872 & 3.692 & 3.590 & 3.359 & 3.039 \\
\hline $\begin{array}{l}\text { Std. } \\
\text { Deviation }\end{array}$ & 0.961 & 0.539 & 1.221 & 0.947 & 1.256 & 1.417 & 1.506 \\
\hline Skewness & -1.613 & -0.794 & -0.706 & -0.658 & 0.057 & -0.032 & 0.453 \\
\hline Kurtosis & 2.096 & -0.562 & -1.104 & -0.028 & -1.741 & -1.426 & -1.667 \\
\hline \multicolumn{8}{|c|}{ Miscellaneous Sector } \\
\hline Ranking & 1 & 2 & 3 & 4 & 5 & 6 & 7 \\
\hline Indicator & $\begin{array}{l}\text { Ability to } \\
\text { think }\end{array}$ & $\begin{array}{l}\text { Interpersonal } \\
\text { Skills }\end{array}$ & $\begin{array}{l}\text { Organization } \\
\text { Skills }\end{array}$ & $\begin{array}{l}\text { Ability to } \\
\text { analyze }\end{array}$ & $\begin{array}{c}\text { Thinking } \\
\text { about } \\
\text { alternatives }\end{array}$ & $\begin{array}{l}\text { Problem- } \\
\text { solving skills }\end{array}$ & $\begin{array}{c}\text { Strategic } \\
\text { Planning } \\
\text { Skills } \\
\end{array}$ \\
\hline Mean & 4.482 & 4.407 & 4.100 & 3.741 & 3.667 & 3.370 & 3.259 \\
\hline $\begin{array}{l}\text { Std. } \\
\text { Deviation }\end{array}$ & 0.826 & 1.088 & 0.396 & 1.234 & 1.328 & 1.131 & 1.180 \\
\hline Skewness & -1.568 & -1.581 & -0.385 & -0.651 & -0.320 & 0.137 & -0.697 \\
\hline Kurtosis & 1.560 & 0.972 & -0.391 & -0.837 & -1.764 & -0.836 & -0.931 \\
\hline
\end{tabular}


The items that are loaded against factor-I (Organization skills) are OS-1, OS-2, OS-3, and OS-5. The items that are loaded against factor-II (Interpersonal skills) are IPS1, IPS2, and IPS3. The items that are loaded for factor-III (Ability to analyze) are AA1, AA2, and AA4. Factor IV (Problem Solving skills) extracted items that are PS1, PS2, and PS4. Similarly, the factor-V (Strategic Planning skills) extracted items that are SPS1, SPS2, and SPS4. Factor VI (Ability to think) extracted items that are ATT1, ATT2, and ATT3. Lastly, factor VII (Thinking about alternatives) extracted two items that are TAS2, and TAS3. In the case of reliability of the scale, all the factors demonstrated a higher level of reliability (Cronbach alpha) which is greater than the threshold value of 0.60 (ㅂair, 2009). With these Alpha values and the commonalities between the items, it is indicated that this instrument is suitable for the present analysis and studies in this thematic context in further researches when utilizing it with these factors.

While in the case of ranking of factors Ability to think has been found most demanding skills on the ranking scales based on mean attribute score (MAS) with a mean value of 4.374 and standard deviation of 0.933 . On the other hand, strategic planning skills remained on the last degree of the skills requirement scale. From the perspective of the textile sector industry, the Ability to analyze is found at a higher level while problem-solving skills remained at least scale. Similarly, in the case of the cellular sector, the service sector and miscellaneous sector (industries) deemed the Ability to think as the most demanding skills. While the banking sector deems organizational skills as the most valuable skills. This state of affairs indicates that the Ability to think is the most pre-dominant skill, required in most industries. Thus, business schools should focus on developing the Ability to think skills among the business graduate (Table 5).

\section{CONCLUSION}

This study data reveals a gap between Academia and industry regarding the improvement of necessary skills of business graduates in public and private sector students. Although Academia is contributing in full swing to enhance the skills of business graduates, however business schools must have a liaison on a regular basis with the industry to bridge the gap between Academia and industry regarding the improvement of business graduates.

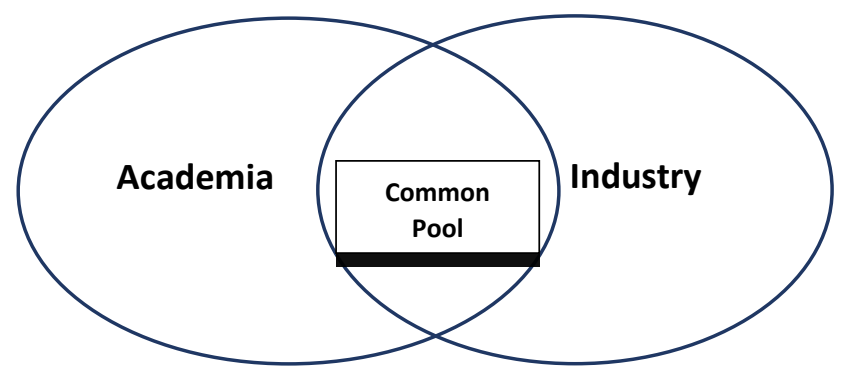

Figure 1: A diverse pool of industry and Academia

A diverse pool of industry and Academia (figure 1) must be developed to understand the needs of industry Academia where both industry and Academia should meet regularly to bring harmony among industry needs and solutions being provided by the Academia. From the perspective of Industry Professionals, it has been pointed after analyzing the thematic coding of qualitative insights that according to the industry professionals, business graduates are not up to the mark prepared to enter into the job market. For this purpose, industry professionals have recommended improving the skills of business graduates to meet the industry requirements in the dynamic world. They should be given more practical knowledge and should be taught through local business case studies to abridge them with the local problems that the industry faces. More specifically, they must be given confidence by their parent institutes to deal with complex situations. Accordingly, they must be trained to become a good leader in the business environment and should have to learn ethical and social norms along with business ethics. Such case studies are given to students from which they must have to learn the discipline.

Industry professionals deem the Ability to think as the most critical attribute among business graduates. Moreover, Higher Education Commission Pakistan and other stakeholders must try to promote and encourage the usage of local and global case studies simultaneously to improve the skills of the business graduates, so the need of local industry must be catered to. Most importantly the $43 \%$ of industry professionals have shown dissatisfaction regarding the skills of business graduates, which indicates that Academia is far behind in developing and delivering a pool of qualified business graduates who can serve the local needs. At the academic level, universities must have to be proactive in connection with the changing and vibrant market demands. They should devise their business education programs accordingly, keeping in view the needs of the industry. More specifically, the degree-awarding institutes should set up committees at their department level/business schools to liaison with the industry to train their business graduates accordingly. Industry professionals must have collaborated with business schools to update Academia on their needs for business graduates. Business schools must have developed a pool of local firms' case studies, this will improve the understandings of the students to absorb the local industrial environment. Collaboration among the academic entities must be promoted to share the experiences and knowledge for the betterment of business graduates. Industry professionals must be invited by academic institutes to share their practical experience among business graduates so that they can learn real-time experiences from the industry 


\section{LIMITATION AND STUDY FORWARD}

This study is not free from potential limitations. Frist limitation of this study is related to its sample size, which is small, however, in the future large sample size can provide important insights. Secondly, limited sectors were approached for data collection; thus, adding other sectors can provide useful insights in the future. Other stakeholders,' i.e., students and teachers, have not been included in this study, and their perception in this regard is not explored. Thus, adding this continuum in future studies can generate a broader picture. In the future, factors identified in this study can be tested empirically, which is another unexplored dimension of this study. Moreover, adding qualitative insights from all the stakeholders can bring very useful insights in the future.

\section{ACKNOWLEDGEMENT}

This research was financially supported by the Higher Education Commission (HEC) of Pakistan (Project No. $6(01) / \mathrm{Acad} / \mathrm{SS} \& \mathrm{H} / \mathrm{HEC} / 2017 / 77$ under the thematic research grant program (TRGP).

\section{AUTHORS CONTRIBUTION}

Dr. Muhammad Abrar conceptualized the study and identified the research area, and worked on the first and last section of this manuscript. While Dr. Sajjad Baig drafted the questionnaire for data collection. Dr. Rizwan Shabbir worked on the introduction and literature section. Dr. Shahnawaz Saqib, collected data and performed data analysis, and wrote the results section. Dr. Mohsin Bashir coordinated all the activities and prepared the final draft.

\section{REFERENCES}

1. Barnes, L. B., Barnes, L. B., Christensen, C. R., Barnes, L. B., Hansen, A. J., \& Hansen, T. L. (1994). Teaching and the case method: Text, cases, and readings. Harvard Business Press.

2. Bekkers, R., \& Freitas, I. M. B. (2011). The performance of university-industry collaborations: Empirical evidence from the Netherlands. DRUID 2011 Summer Conference, Held, 15-17.

3. Bell, R. (2020). Developing entrepreneurial behaviours in the Chinese classroom through value creation pedagogy. Innovations in Education and Teaching International, 1-12. https://doi.org/10.10 $\underline{80 / 14703297.2020 .1793800}$

4. Bennis, W. G., \& O'Toole, J. (2005). How business schools have lost their way. Harvard Business Review, 83(5), 96-104.

5. Bratianu, C., Stanescu, D. F., \& Mocanu, R. (2021). Exploring the knowledge management impact on business education. Sustainability, 13(4), 2313. https://doi.org/10.3390/su13042313

6. Campbell, J. L. (2007). Why would corporations behave in socially responsible ways? An institutional theory of corporate social responsibility. Academy of Management Review, 32(3), 946-967. https://doi.org/10.5465 lamr.2007.25275684

7. Cavaye, A. L. M. (1996). Case study research: A multi-faceted research approach for IS. Information Systems Journal, 6(3), 227-242. https://doi.org/10.1111/j.1365-2575.1996.tb00015.x

8. Cavico, F. J., Heron, T., Mujtaba, B. G., \& Pellet, P. (2007). Ethics and Information Technology Professionals: An Examination of Gender, Age, Career Stage, Education Level and Ethics Training Variables.

9. Cavico, F. J., \& Mujtaba, B. G. (2009). The state of business schools, business education, and business ethics. Journal of Academic and Business Ethics, $2,1$.

10. Christensen, C. M., \& Raynor, M. E. (2003). Why hard-nosed executives should care about management theory. Harvard Business Review, 81(9), 66-75.

11. Conger, J. A., \& Xin, K. (2000). Executive education in the 21st century. Journal of Management Education, 24(1), 73-101. https://doi.org/10.1177/105256290002400106

12. Cruikshank, J. L. (1987). A delicate experiment: the Harvard Business School, 1908-1945. Harvard Business Press.

13. Donnorummo, B. (2002). The emerging markets and the process of globalization. In The Emerging Markets and Higher Education (pp. 25-46). Routledge. https://doi.org/10.4324/9780203903353-8

14. Etzkowitz, H., \& Leydesdorff, L. (2000). The dynamics of innovation: from National Systems and "Mode 2" to a Triple Helix of university-industry-government relations. Research Policy, 29(2), 109-123. https://doi.org/10.1016/S0048-7333(99)00055-4

15. Garvin, D. A. (2003). Making the case. Harvard Magazine, 106(1), 56-65.

16. Gibb, A., \& Price, A. (2014). A compendium of pedagogies for teaching entrepreneurship. International Entrepreneurship Educators Program.

17. Gioia, D. A., \& Corley, K. G. (2002). Being good versus looking good: Business school rankings and the Circean transformation from substance to image. Academy of Management Learning \& Education, 1(1), 107120. https://doi.org/10.5465/amle.2002.7373729

18. Gloeckler, G. (2005). Head of the class: Executive education programs that deliver real-world examples get the highest ratings. Business Week, 24.

19. Grant, R. (1997). A claim for the case method in the teaching of geography. Journal of Geography in Higher Education, 21(2), 171-185. https://doi.org/10.1080/03098269708725423 
20. Hair Jr, J. F., Hult, G. T. M., Ringle, C., \& Sarstedt, M. (2016). A primer on partial least squares structural equation modeling (PLS-SEM). Sage Publications. https://doi.org/10.15358/9783800653614

21. Herreid, C. F. (2011). Case study teaching. New Directions for Teaching and Learning, 2011(128), 31-40. https://doi.org/10.1002/tl.466

22. Herreid, C. F., \& Schiller, N. A. (2013). Case studies and the flipped classroom. Journal of College Science Teaching, 42(5), 62-66.

23. Hoag, K. A., Lillie, J. K., \& Hoppe, R. B. (2005). Piloting case-based instruction in a didactic clinical immunology course. American Society for Clinical Laboratory Science, 18(4), 213-220.

24. Jain, A. K. (2005). Management education and case method as a pedagogy. Vikalpa, 30(1), 77-84. https://doi.org/10.1177/0256090920050107

25. Kolachi, N. A., \& Wajidi, A. Z. (2008). Business education in Pakistan: Identifying weaknesses and suggesting improvements. East West Journal of Economics and Business, 11(1-2).

26. Leydesdorff, L., \& Etzkowitz, H. (1998). The triple helix as a model for innovation studies. Science and Public Policy, 25(3), 195-203.

27. Liedtka, J., \& Ogilvie, T. (2011). Designing for growth: A design thinking tool kit for managers. Columbia University Press.

28. Mahmood, K., \& Shafique, F. (2010). Changing research scenario in Pakistan and demand for research qualified LIS professionals. Library Review, 59(4), 291-303. https://doi.org/10.1108/00242531011038596

29. Mars, M. M., \& Rhoades, G. (2012). Socially oriented student entrepreneurship: A study of student change agency in the academic capitalism context. The Journal of Higher Education, 83(3), 435-459. https://doi.org/10.1353/jhe.2012.0015

30. McMahon, G. (2009). Critical Thinking and ICT integration in a Western Australian secondary school. Journal of Educational Technology \& Society, 12(4), 269-281.

31. Merseth, K. K., \& Lacey, C. A. (1993). Weaving stronger fabric: The pedagogical promise of hypermedia and case methods in teacher education. Teaching and Teacher Education, 9(3), 283-299. https://doi.org/10.10 16/0742-051X(93)90044-H

32. Ministry of Federal Education and Professional Training Government of Pakistan. (2015-16). Pakistan Education Statistics: National Education Management Information System, Academy of Educational Planning and Management.

33. Nind, M. (2020). A new application for the concept of pedagogical content knowledge: Teaching advanced social science research methods. Oxford Review of Education, 46(2), 185-201. https://doi.org/10.1 080/03054985.2019.1644996

34. Nind, M., \& Lewthwaite, S. (2018). Methods that teach: Developing pedagogic research methods, developing pedagogy. International Journal of Research \& Method in Education, 41(4), 398-410. https://doi.org/ 10.1080/1743727X.2018.1427057

35. Orlikowski, W. J., \& Baroudi, J. J. (1991). Studying information technology in organizations: Research approaches and assumptions. Information Systems Research, 2(1), 1-28. https://doi.org/10.1287/isre.2.1.1

36. Pfeffer, J., \& Fong, C. T. (2002). The end of business schools? Less success than meets the eye. Academy of Management Learning \& Education, 1(1), 78-95. https://doi.org/10.5465/amle.2002.7373679

37. Porter, L. W., \& McKibbin, L. E. (1988). Management education and development: Drift or thrust into the 21 st Century?. ERIC.

38. Read, C. W., \& Kleiner, B. H. (1996). Which training methods are effective? Management Development Review, 9(2), 24-29. https://doi.org/10.1108/09622519610111781

39. Waddock, S., \& Lozano, J. M. (2013). Developing more holistic management education: Lessons learned from two programs. Academy of Management Learning \& Education, 12(2), 265-284. https://doi.org/10.5465/ amle.2012.0002

40. Yin, R. (1984). Case study research. Beverly Hills. CA: Sage.

41. Zgaga, P., Klemencic, M., Komljenovic, J., Miklavič, K., Repac, I., \& Jakacic, V. (2013). Higher education in the Western Balkans: reforms, development, trends. Key findings from field research. Faculty of Education, University of Ljubljana. 